\title{
Making the Perfect Queen: The Cultural Production of Identities in Beauty Pageants
}

\author{
Rebecca Chiyoko King-O'Riain* \\ National University of Ireland
}

\begin{abstract}
Beauty queens are symbolic representations of collective cultural indentities and beauty pageants are fields of active 'cultural production'. This article surveys the growing literature on beauty pageants to better understand how culture is produced within the contexts of pageants. To do so, the article examines how beauty pageants operate as sites of commodification and consumption in a world increasingly influenced by global markets and media institutions. It also illustrates how culture is produced in beauty pageants by examining beauty pageants as sites of oppression, sites to articulate cultural agency, and sites of ethnic, gender, cultural, and sexual identity production.
\end{abstract}

Beauty pageants, whether on the local or global stage, are lively sites for the production and contestation of cultural meanings. They are fascinating cases for sociologists interested in revealing the processes of collective cultural production. Following the turn from the sociology of culture to 'cultural sociology' (Becker 1984), studies of popular culture have moved to focus not just on cultural objects or symbols as texts, but also to delve into the processes of their production. Beauty pageants are sites rich in both symbolism and cultural production and have much in common with other popular cultural production sites such as talk shows (Gamson 1998), cheerleading teams (Grindstaff and West 2006), and youth car modification (Best 2006). Through the rehearsals, judging and selection of beauty queens each year (often at cultural festivals), beauty pageants reveal processes that social groups go through in defining, debating, and changing their cultural identities.

The beauty queen is a person (typically a woman) chosen by a group of people to serve as a symbolic representation of their collective identity to a larger, often national, audience. Typically, beauty queens are chosen through beauty pageants or contests, which can vary by social context, setting, and judging criteria. During her reign, a beauty queen often makes symbolic appearances at public functions wearing a tiara (crown) and sash (often emblazoned with the title she holds and/or her sponsor's 
name), but she is shaped, selected, and even produced within the social context of the institution of the beauty pageant.

In an early study of beauty pageants, Riverol (1992) traced the history of national identity in the Miss America pageant, as mediated by television coverage, allowing members of the 'nation' a first chance to see their queen being chosen. Banet-Weiser (1999) analyses the Miss America pageant in relation to national, cultural, gender, and racial rearticulation over time. Craig (2002) highlights the process of the emergence of counterhegemonic, African American notions of beauty in response to mainstream white American understandings of beauty. Others examine the global impact of beauty pageants in different countries and in different settings; from the spread of the Miss Universe pageant (modeled on the American format of beauty pageants) to the evolution of 'local' nonpyramidal pageants that seem to operate almost in response to the widening of the American beauty pageant model (Cohen et al. 1996). Many of these studies view beauty pageants as cultural forms that produce meanings of nation, ethnicity, race, and gender. Most of the studies are based on the authors' experiences (either in person via television or through historical documents analyzed as texts) as audience members or viewers of the pageant.

However, beauty pageants are not only 'texts' to be read and analyzed, but also sites of action and interaction generating a process of cultural production that is deeply linked to claims to cultural authenticity, race, gender, and identity. Beauty pageants are not only places where queens are chosen but where they are made. In this sense, beauty pageants can be seen as cultural forms of collective self-identity as well as embodied production points of cultural identity. This two-sided approach is common to much of the current sociology of culture. For example, analysis of collective memory has been impacted by studies of embodiment. Spillman and Conway find though that many make 'too sharp a distinction between incorporated or embodied memory and textual or discursive memory and ignore the complex relations between them ... we need to theorize how bodily memories are always already inscribed, organized and symbolized' (2007, 81). Beauty pageants lend themselves well as a case study to understanding the linkages between bodies and textual memories because they are at once about both embodied symbols and symbolic bodies, created and chosen through a process of inscription each year in the selection of the beauty queen. The beauty queen is more than just the actor performing a ritual of collective cultural identity, but also a 'shared system of elective representations, observers/audiences, means of symbolic production, misen-scene, and social power' (Alexander 2004 as paraphrased in Spillman and Conway 2007, 88).

The beauty pageant, while perhaps in decline in the industrialized world, is a growing cultural institution in diverse countries such as Nicaragua, the Philippines, Belize, and Liberia. Interestingly, the format and the script of the pageant are amazingly similar across many different nations, 
cultures, and societies (Cohen et al. 1996). Most pageants have similar components: question and answer, interview, evening gown, traditional dress, and talent. Often the format of the judging criteria and the 'events' that make up the pageant - even the emcee performances - are arranged in a predictable and unchanging fashion. There are also similar cultural scripts that get enacted and invoked within the pageants such as 'it isn't about beauty, it's about culture' and 'I don't want to win, I just want to participate to serve the community'. Bodily practices like holding hands as the name of the winner is read, crying tears of joy (no tears of loss or disappointment allowed, it is not lady like) are also highly homogeneous across many different social and cultural contexts. Even the audience has fairly predictable scripted behavior of cheering for their favorite, no booing, and appearing 'shocked and pleased' by the winner (King-O'Riain 2006).

This paper examines the growing literature on beauty pageants to better understand how culture is produced within the contexts of pageants. To do so, I look at beauty pageants as sites of commodification and consumption in a global world influenced by global markets and media institutions. I then examine how culture is produced in beauty pageants examining beauty pageants as sites of oppression, sites to articulate cultural agency, and sites of ethnic, gender, cultural, and sexual identity production.

\section{Producing culture in beauty pageants}

Beauty pageants are cultural expressions that take many forms; however, studies of pageants fall into the following four general areas: those that see the pageants as sites of increasing globalization, as sites of oppression, sites to articulate cultural agency, and sites of ethnic, gender, cultural, and sexual identity production.

\section{Pageants as sites of commodification and consumption in a global world}

In the past, beauty pageants in the USA had global undertones to them as Miss America was often chosen to represent the 'nation' to the global world. Today, however, even the most local beauty pageants are also increasingly commercialized by their position within the global beauty industry. Often beauty pageants are driven by transnational corporations across the globe trying to capture emerging markets in places like India and China with increasingly Western notions of beauty driving their cosmetic campaigns.

The continued valorization of 'whiteness' or 'lightness' and European beauty standards seem to be impacting the Miss World and Miss Universe pageants even with an increase in the proportion of women of color named as queens. Rondilla and Spickard (2007) tackle this when they ask, 'Is Lighter Better?' in relation to Asian American women and find that the answer is almost always 'yes'. 
Ashikari (2005) likewise, studied whiteness in Japan and found a strong preference for light complexions in Japan with 'whitening' cosmetics sales on the rise. 'White skin is not just class or obsession with the west, but a symbolic physical characteristic for identifying the Japanese people' (Ashikari 2005, 73). She finds that Japanese women do not use products with bleach, but see themselves as protecting white skin or recovering their 'innate' white tone.

Through the use of super high-tech whitening cosmetics, Japanese women are cultivating a Japanese form of whiteness which is based on the Japanese identity as a race, and, therefore, very different from - and even 'superior' to - western whiteness (Ashikari 2005, 89).

Obsession with whiteness, and the cosmetic industry that will help achieve it, is not the only way that beauty queens are commodified. Even beauty queens in local pageants have sponsors from local businesses, but the real money is to be made on the global stage. A number of third world countries have recently hosted large international pageants both as a form of economic development (say of their tourist industry), but also as a way to make business contacts with the West.

The more recent Miss World and Miss Universe pageants have been held in developing countries: India, Namibia, South Africa, Trinidad and Tobago, to name a few. Whether or not the fact that the global beauty industry is now apparently recognizing black beauty will change the nature of the class and racial politics in Caribbean beauty pageants remains to be seen. However, given the intimate relationship between international beauty pageants and American corporate finance, it may be closer the mark to suggest that it is not racial progress per se that is changing the face of pageant winners but rather the strategic move to open Third World markets to First World business by embracing Third World nationalist symbols (Edmondson 2003, 10-11).

These global tensions become clearer when Oza (2001) examines the local protests in India during the 1996 Miss World pageant in Bangalore, India.

State and supporters of the pageant provided an international opportunity to 'showcase' new, liberalized India to the world. The pageant, therefore, was a site at which political protest and anxiety with 'globalization' as well as the opportunity to showcase India to the world were articulated (Oza 2001, 1067).

The Miss World pageant was seen as iconic of global influences forcing their way into India. Local protesters did not challenge the symbolism of the pageant itself, in terms of the agency of women, but instead protested the pageant as the impact of globalization and its attempt to threaten local culture.

When Trinidad and Tobago hosted the Miss Universe contest in 1999, there was little local protest because the region saw it as a form of prospective global economic development. 
Seeking a chance to create economic opportunities for Trinidad by showcasing the country's rich cultural heritage, the government hoped to introduce the 'international' (that is, First World) audience to Trinidad as a desirable tourist destination. Also, the large and small business communities desired to make money from the event and to build business contacts with the likes of Donald Trump, who owns the Miss Universe franchise. (Edmondson 2003, 13)

Similarly, ‘... The Miss Venezuela pageant is close to a national industry, a precious natural resource, like oil, to be developed and sold abroad for the enrichment of the nation' (Edmondson 2003,14). But this does little to challenge or change the 'white, Western' notions of beauty in the pageant. In fact, both India and Venezuela have recently sent taller, more Western-looking women forward to international pageants because they want a queen that will win on the global stage.

But viewing beauty pageants only in terms of the contexts in which they take place, as a product consumed and viewed by audiences is only one part of the production process. One must also consider the backstage production side of them as well. When you get backstage, for long periods of time, you see that beauty pageants are contrived performances, like many others, that take much practice and effort to make them appear natural and free flowing.

\section{Pageants as sites of oppression}

Beauty pageants have been seen by many scholars as 'low brow' cultural events that reinscribe patriarchal images of ideal beauty rarely attained by most women (Wolf 1991). White feminists (Faludi 1992) have been particularly vocal about the harm that beauty pageants have done and continue to do in perpetuating unattainable bodily and appearance norms. While much of the critique of pageants is clear and irrefutable - judging in pageants objectifies women as symbols and women's bodies are used to promote commercial goods - a blanket refusal to analyze beauty pageants also means that sociologists might not understand their continuing (and even, in some parts of the world, growing) popularity. In most pageants, the women that participate are keenly aware of feminist critiques of pageants and in some ethnic pageants equate feminism with 'white women' and thus recast their own participation as feminism, but of a different kind. They argue that speaking out on stage fundamentally is a feminist move within Japanese American cultural institutions because they focus the voice and platforms of women within the community (King-O'Riain 2005, 209). Others such as Yano (2006), in analyzing the Honolulu Japanese American Cherry Blossom Queen Pageant explains how pageants use culture to, '... not offer counter hegemonic rewards so much as reproduce conservative, gendered expectations, ideals and practices' (Yano 2006, 38). By casting themselves as 'cultural pageants', the Cherry Blossom Queen Pageant organizers in Honolulu hoped to side step the most 
exploitative aspects of the 'beauty pageant' (bathing suit competitions and the like) and use 'culture' as a rationale for how they are different from pageants such as Miss World and perhaps more palatable to feminist critics.

\section{Pageants as sites to articulate cultural agency}

Craig (2002) argues that women of color have often used 'beauty' as a response and counter to white notions of beauty. In Ain't I a Beauty Queen? (2002), Craig argues that

The culture that the black middle class produced, as seen in beauty contests, was never a simple replica of the dominant culture, which itself was heterogeneous. As black community institutions, beauty contests were neither fully autonomous nor fully dominated; they incorporated but altered prevailing discourses of race, gender and class. (p. 64)

This was true because the beauty contests were open to the judgment of the black public and the queen a representative of them.

Many ethnic pageants within the USA have developed as a response to the exclusion (first real and then more symbolic) of women of color and other ethnic communities. The evolution of the Miss Vietnam USA, Miss Chinatown USA, Miss Ethiopia North America (first held in 2005), Miss India USA, Miss Latina USA (Fears 2005), and even white-ethnic pageants like the Irish Rose of Tralee pageant are seen as validation that ethnic women and their culture are beautiful.

However, ethnic beauty pageants never really have the agency to diverge completely from the European American beauty ideal as reified in Miss Universe or Miss World pageants or global beauty culture at large. Ethnic pageants often took place within a debate between assimilation and cultural pluralism. Kurashige (2002) argues that the growing interest in beauty pageants and the format they took in the Japanese American community in Los Angeles after World War II, was driven by a desire to be seen as $110 \%$ American.

Within these debates what became key was the 'authenticity' of the culture being venerated (Lieu 2000). Often the performance of culture in the pageant (through dance routines or talent performances) was contrived and changing notions of cultural performances were performed for consumption by an audience like tourist performances of the 'hula' and the like. They were attempts to give the audience a 'taste' of the culture being reproduced (no matter how authentic) for the purposes of the pageant itself.

Pageants as sites of ethnic, gender, cultural, and sexual identity production

Beauty pageants can be sites of oppression and agency, but they are also contested sites of the production of cultural identity. Beauty pageants are 
often the subject of debates about the future of ethnic communities, in part because they are public spectacles that allow women from within communities to voice their concerns, but also because they are a vehicle for conveying anxiety about collective identity. The beauty queen herself is often a field on which debates about collective identity can safely take place in the public sphere. Culture in these pageants, is both the judging criteria and the prize. In this sense, beauty pageants can also link the creation of cultural and racial meanings at both the micro- (within and between people) and macro- (within and between groups, organizations, and institutions) levels of social interaction (King-O'Riain 2006).

\section{Rules}

For this reason, not just anyone can participate in a beauty pageant. There are eligibility rules that guide the characteristics of who can run in the beauty pageant, the criteria of the selection, and who can become queen each year - not everyone can be trained to be royal. Typically, the rules require that the women participating be between 18-26 years of age, be unmarried, and not have had children. In racial/ethnic community pageants, there are often rules about racial purity (must be of at least $50 \%$ Japanese ancestry) or that candidates be able to speak a particular language. There are also unspoken rules and assumptions that the queen be heterosexual. Discussions of sexuality and even the presence of boyfriends are very strictly controlled in some pageants. The sexuality of the contestants is rarely emphasized and not mentioned lest it sully the character of the title itself. Cases, such as the dethroning of then Miss America, Vanessa Williams, for posing nude, and in a potential lesbian situation for Playboy magazine, highlight the heterosexist assumptions of sexuality when it comes up at all (Banet-Weiser 1999). As Blum writes, 'the pageant still defines respectability as a virginal, heterosexuality, passive, unawakened, and awaiting marriage' (2002, 312).

Race can also be a deciding factor in cultural pageants in terms of who can represent nations or groups of color, but it is not always the only factor. Miss Jamaica 1976, Cindy Breakespeare (who later became Miss World), was an extremely popular queen. Even though she was white, she,

was perceived to be a part of the new cultural order, a woman who embraced 'roots' or popular Jamaican culture and who had a public relationship with Jamaica's international black working class icon, the reggae superstar Bob Marley. It is not merely race alone, then, that determines the meaning of the beauty queen's appeal but also whether or not she is seen to represent the interests of the country at large. (Edmondson 2003, 9)

In this case, representing the local culture superseded the importance of race in representing 'Jamaicaness' to the local community and the world. 
In a study of Mayan Indian beauty pageants in Guatemala, Schackt (2005) argues that the pageants created a vehicle for the celebration of Mayanhood through beauty.

All participants are Maya Indians and must wear the traditional folk costume of their native township. The intention of this and other Indian pageants has been to preserve and reinvigorate traditional forms of cultural expression. Indian queens are elected not so much on the basis of their looks as on their aptitude for representing cultural 'authenticity'. (Schackt 2005, 269)

The argument that it is a cultural - not a beauty - pageant is common in cultural pageants such as those that purport to reward cultural 'authenticity', cultural practices and preserve cultural traditions. However, they do so by choosing a woman as a symbol of all of this 'culture'. The pageant in the Mayan case became a venue for conflict between traditional folklorist types of orientations and more recent politicized Mayanist agendas.

The 'authenticity' that Schackt (2005) describes is difficult to unpick. Is it only a Western concept (Handler 1986) or is deeply entangled with the inauthenticity that is implied by the commodification of cultural symbols (Friedman 1994 in Schackt 2005, 269)? Certainly in my own fieldwork in Japanese American beauty pageants in Los Angeles, San Francisco, and Honolulu, participants and organizers of the pageants felt they were striving for an 'authentic' cultural experience. The organizers 'trained' the queen and her court in Japanese traditional arts (kimono, taiko, tea ceremony, etc.) in order to ensure cultural competence during their reign. They do this in part to dissuade critical comments from within Japanese American communities about how assimilated, or nonculturally Japanese, the queens are. They are also cognizant of their symbolic and often financial ties with 'homeland' Japanese companies who sponsor the pageants and seek a particular version of authenticity (King-O'Riain 2006).

But the beauty pageants and their meanings can be contradictory as well as contested. For example, within the Chinese American community there was concern when a half black Miss Chinatown candidate (Chong 2006) competed in 2006. There was a fear of 'losing culture' through mixed race candidates as well as a pride in the community becoming multicultural.

\section{Conclusions}

This paper has meant to provide an overview of the subfield of beauty pageants but also as a case for understanding the role of cultural production within the globalizing beauty pageant industry. Beauty pageants allow us to examine meaning-making within fields of institutions or networks by seeing culture as a socially constructed product by revealing the processes that go into their making.

Beauty pageants are interesting cultural production sites that reveal the impact that global beauty markets are having on commodification and 
consumption within the pageant world themselves. They are also sites where one can see oppression and attempts at agency in cultural terms to negotiate beauty meanings. Beauty pageants also produce beauty queens that symbolize collective identities and produce those same identities in racial, ethnic, gender, and cultural terms through the pageant.

Beauty pageants are public events where decisions about who the queen will be and what she will represent in cultural, racial, and gendered terms during her reign, provide a space for discourse and cultural action in ethnic and national communities. Beauty pageants in this sense are not just descriptions of the temperatures of communities in terms of highethnic feeling or low-ethnic awareness; they are constitutive of that same feeling. They both provide a field for debates about culture while also creating the culture and collective meaning that is to be debated. Racial and ethnic beauty pageants require individual candidates to develop sets of cultural skills used to make authenticity claims to be queen, but these are exercised within a collective and communal gaze.

\section{Short Biography}

Dr. Rebecca Chiyoko King-O'Riain is a Senior Lecturer at the National University of Ireland, Maynooth. Her book Pure Beauty: Judging Race in Japanese American Beauty Pageants (University of Minnesota Press, 2006) examines the use of blood quantum rules in Japanese-American beauty pageants. She is also doing research on Polish and Chinese immigrants in Ireland, the Irish Census and on the 'Globalization of Love'.

\section{Note}

* Correspondence address: Department of Sociology, National University of Ireland, Maynooth, Maynooth, County Kildare, Ireland. Email: rebecca.king-oriain@nuim.ie.

\section{References}

Ashikari, Mikiko 2005. 'Cultivating Japanese Whiteness: The "Whitening" Cosmetics Boom and the Japanese Identity.' Journal of Material Culture 10: 73-91.

Alexander, Jeffrey C. 2004. 'Cultural Pragmatics: Social Performance between Ritual and Strategy.' Sociological Theory 22: 527-573.

Banet-Weiser, Janet 1999. The Most Beautiful Girl in the World: Beauty Pageants and National Identity. Berkeley, CA: University of California Press.

Becker, Howard 1984. Artworlds. Berkeley, CA: University of California Press.

Best, Amy 2006. Fast Cars, Cool Rides: The Accelerating World of Youth and Their Cars. New York: New York University Press.

Blum, Linda M. 2002. 'Body Wars, the Clash of the Paradigms.' Qualitative Sociology 25: 305-14. Chong, Jia-Rui 2006. 'Tiaras, Sashes, Diversity'. Los Angeles Times Saturday, April 22: A01.

Cohen, Colleen Ballerino, Richard Wilk and Beverly Stoeltje 1996. Beauty Queens on the Global Stage: Gender, Contests, and Power. New York: Routledge.

Craig, Maxine Leeds 2002. Ain't I a Beauty Queen? Black Women, Beauty and the Politics of Race. New York: Oxford University Press. 
Edmondson, Belinda 2003. 'Public Spectacles: Caribbean Women and the Politics of Public Performance.' Small Axe March: 1-16.

Faludi, Susan 1992. Backlash: The Undeclared War Against American Women. New York: Anchor Books.

Fears, Darryl 2005. 'Ethnic Pageants Restyle the American Beauty Contest.' Washington Post October 19: A01.

Friedman, J. 1994. 'Globalization and Localization.' In Cultural Identity and Global Processes. London: Sage Publications.

Gamson, Joshua 1998. Freaks Talk Back: Tabloid Talk Shows and Sexual Nonconformity. Chicago, IL: University of Chicago Press.

Grindstaff, Laura and Emily West 2006. 'Cheerleading and the Gendered Politics of Sport.' Social Problems 53: 500-18.

Handler, R. 1986. 'Authenticity.' Anthropology Today 2: 2-4.

King-O'Riain, Rebecca Chiyoko 2005. 'Miss Cherry Blossom Meets Mainstream America.' Pp. 204-21 in East Main Street: Asian American Popular Culture, edited by Shilpa Dave, Leilani Nishime and Tasha G. Oren. New York: New York University Press.

King-O'Riain, Rebecca Chiyoko 2006. Pure Beauty: Judging Race in Japanese American Beauty Pageants. Minneapolis, MN: University of Minnesota Press.

Kurashige, Lon. 2002. Japanese American Celebration and Conflict: A History of Ethnic Identity and Festival 1934-1990. Berkeley, CA: University of California Press.

Lieu, Nhi T. 2000. 'Remembering "The Nation" Through Pageantry: Femininity and the Politics of Vietnamese Womanhood.' Frontiers 21: 127-52.

Oza, Rupal 2001. 'Showcasing India: Gender, Geography and Globalization.' Signs 26: 10671095.

Riverol, A. R. 1992. Live From Atlantic City: The History of the Miss America Pageant Before, After and in Spite of Television. Bowling Green, OH: Bowling Green State University Popular Press.

Rondilla, Joanne L. and Paul Spickard 2007. Is Lighter Better? Skin Tone Discrimination Among Asian Americans. New York: Rowman and Littlefield.

Schackt, Jon 2005. 'Mayahood Through Beauty: Indian Beauty Pageants in Guatemala.' Bulletin of Latin American Research 24: 269-87.

Spillman, Lyn and Brian Conway 2007. 'Texts, Bodies and the Memory of Bloody Sunday.' Symbolic Interaction 30: 79-103.

Wolf, Naomi 1991. The Beauty Myth: How Images of Beauty Are Used Against Women. New York: William Morrow and Company.

Yano, Christine R. 2006. Crowning the Nice Girl: Gender, Ethnicity and Culture in Hawai'i's Cherry Blossom Festival. Honolulu, HI: University of Hawai'i Press. 